\title{
READABILITY OF COMPREHENSION PASSAGES IN JUNIOR HIGH SCHOOL (JHS) ENGLISH TEXTBOOKS IN GHANA
}

\author{
Charles Owu-Ewie
}

\begin{abstract}
Understanding what is read is essential to academic success in general and literacy development in particular. The aim of any textbook, especially English language textbooks for second language learners is to help readers improve their English language competence. This aim is defeated when students cannot read texts intended for them. One factor which makes a reading material unreadable is the complexity of the language used in relation to the reading ability of the reader. Research has shown that most materials meant for second language learners are difficult for the intended readers. It is therefore crucial to determine the readability of comprehension passages in Junior High School (JHS) English language textbooks used in Ghana and also to examine what can be done to improve L2 text writing in Ghana to make materials readable. This paper, therefore used The Gunning FOG Readability test, Flesch Reading Ease Formula, Flesch-Kincaid Grade Level, SMOG Index, Coleman-Liau and Automated Readability Index readability formulas to determine the readability of 48 comprehension passages purposively selected from four different sets of JHS 1-3 English language textbooks. It was found that most of the passages were above the age of learners and were therefore difficult for them to read and comprehend. The study through interviews examined ways that writing of JHS English textbooks can be improved to enhance readability.
\end{abstract}

Key Words: readability formulas, comprehension passages, Junior High School, textbook

http://dx.doi.org/10.4314/gjl.v3i2.3

\section{Introduction}

Reading is essential to success in school and lifelong learning. It is even more crucial in second language learning where students need to read to improve their vocabulary and communication skills (Grabe \& Stoller 2002). Reading is fundamental 
to students in a variety of situations and professions. It is an important skill for success in the $21^{\text {st }}$ global digital century. Reading development is an important element of a student's educational/academic career and a major component of highstakes tests, which require higher order reading skills. The ability to effectively comprehend ideas and information expressed by others in writing depends on good reading skills. Reading with understanding is essential to academic success in general and second language literacy development in particular. The level of language used in teaching and in textbooks plays a major role in the academic success of learners. The aim of a textbook, especially an English language textbook for second language learners is to help readers improve their English language competence. This aim is defeated when students cannot read texts intended for them.

Since reading is crucial to academic success, textbooks, work-sheets, and/or examination papers should be readable to learners to make our intent transmittable to the intended learners. How well authors succeed will depend on the readability of the text they produce. An accomplished reader is likely to be bored by unreadable materials, while a poor reader soon becomes discouraged by texts he/she finds too difficult to read fluently. Easy reading helps learning and enjoyment, so what we write should be easy to read (Fry 2006). One factor which makes reading material unreadable is the complexity of language used in relation to the reading ability of the reader. However, research has shown that most materials meant for second language learners are difficult for the intended readers and as a result need to be simplified for easy reading and comprehension. Crossley, McCarthy and McNamara (2006, citing Young 1999) are of the opinion that second language reading texts must be simplified at the beginning and intermediate levels in order to make the text more comprehensible for second language learners and to help prepare them for more authentic texts. The simplification of second language reading texts is supported because they exclude unnecessary and distracting, idiosyncratic styles without suffering a loss of valuable communication features and concepts that are present in authentic text. Writers of second language materials cannot simplify a reading text when they are not aware of the difficulty level of the text. They should know the age of the readers and what they are capable of reading at that level. This can be achieved by using a readability formula to test the text. Teachers give students handouts and recommended textbooks but they do not consider the difficulty level of the reading text as well as the ability levels of the students. This may cause difficulty in learning. As Reece and Walker (1992) indicates, difficulties in learning may not be caused only by the way in which we teach, or lack of intelligence of the learner but may be the result of a reading problem; the difficulty of the reading material. To avert this, it is 
crucial to determine the reading difficulty of the comprehension passages we provide for our learners, especially at the Junior High School level. This makes this study crucial because it expands the debate on the Ghanaian JHS learners' inability to read fluently, which has centered mostly on teacher, parent and student factors without considering the difficulty level of reading materials among others as a contributing factor.

\section{Literature Review}

This section takes a critical look at the literature related to the study. It includes the concept of readability, factors affecting readability of a text and readability formulas.

\section{a. What is readability?}

The intention of any writer or author is to transmit information to the reader. Good writing should be highly readable in order to be clearly understood by a wide audience. The concept of readability has been defined in various ways. Readability involves material which is fit to read, interesting, agreeable, attractive and enjoyable (Dubay 2004). It refers to how easy a written text is to read and understand. The ability of a test to consistently measure what it is supposed to measure depends on its readability (Reece \& Walker 1992). This definition is concerned with the interaction between the reader and the text. The readability of a text is a measure of how well and how easily a text conveys the intended meaning to a reader. This implies that when a text cannot be well read and not easily understood it is unreadable. However, Klare (1963) looking at readability from the writer's perspective, defines the term as the ease of understanding due to style of writing. Dubay (2004: 3) writing on The principles of readability noted that the definition by Klare separates writing style from issues such as content and organization of the text.

In another way, McLaughlin (1969) from the perspective of interaction between the text and the reader defines 'readability' as the degree to which a given group of readers finds certain reading materials compelling and comprehensible. Dale and Chall (1949, cited in Dubay 2004) indicate that readability is the sum of the total of all those elements which a given piece of printed material has that affect the success of a group of readers. The success is the extent to which they understand it, read it at an optimal speed and find it interesting. The implication of the definitions above is that comprehensibility is essential in readability. Thus, good written material should be highly readable in order to be clearly understood by a wide audience. 


\section{b. Factors affecting readability of texts}

The ability to read and understand a text depends on a range of factors including content, structure, style, layout and design. These factors can be semantic or syntactic. Semantic factors are concerned with words, while syntactic factors involve the length and structure of sentences. According to Stephens (2000), five style factors likely to affect the readability of a text are the number of pronouns, average number of words in sentences, percentage of different words and number of prepositional phrases. Essem Educational Limited (2007) has indicated a number of factors that influence the readability of a text. These include physical factors (such as typeface, font size, spacing and layout), reader factors (such as prior knowledge, reading ability, and motivation of the reader), vocabulary difficulty, text structure, text coherence and cohesion, and syntax. It must also be noted that the age of the reader is crucial to readability. Age appropriateness of academic material is crucial to effective learning. If the content of a text is above the age of the learner/reader there is bound to be difficulty in reading such a text.

Generally, a text is readable when it presents concrete issues, provides the "who", "what", "where", and "when" familiar to readers, and is also age appropriate. Additionally, the text should be genre-familiar to readers and should be acceptable to the reader's cultural background. According to Stephens (2000), the use of language that is complex, indirect, uneconomical, and unfamiliar affects readability of a text. In addition, the inclusion of needless words, the use of sentence structures that are inevident and ambiguous, and the haphazard and illogical organization of the material affect readability. A critical look at the definitions already provided above indicate that generally readability factors can be categorized into the visual layout of the test, and the ease of understanding of words and sentences in the text. In this study, the latter is the focus.

\section{c. Readability measuring formulas}

Authors rely on variety of approaches to assist them to simplify reading texts for language learners, particularly second language learners, to enable them to make texts more comprehensible. One such approach to evaluate the comprehensibility of texts is readability measures. According to Allen (2009), when material developers want to simplify texts to provide more comprehensible input to second language learners, they generally have two approaches: a structural and an intuitive approach. A structural approach depends on the use of structure and word lists that are predefined by levels, as found in graded reading books. Readability formulas provide an indication of text readability based on the word and sentence length as found in a text. An intuitive 
approach, on the other hand, is a more subjective approach by the author's natural sense of text comprehensibility and discourse processing. Both approaches are commonly used in the development of reading materials. In this study, the six traditional readability formulas mentioned earlier in the abstract will be used to examine the readability of comprehension passages in Junior High School English textbooks in Ghana. According to Crossley, Allen, and McNamara (2011), "traditional reliability formulas are simple algorithms that measure text reliability based on sentence length and word length." (p. 87). Readability formulas were initially developed in the 1920 s in the United States. The first readability study was a response to demands by Junior High School science teachers to provide them with books which would allow them to teach scientific facts and methods rather than to be tied down with teaching science vocabulary necessary to understanding the texts (Stephens 2000). Stephens' initial probing of readability began with asking students, librarians, and teachers what makes a text readable. Readability formulas are used to predict reading ease but they do not help us evaluate how well the reader will understand the ideas in the text. Traditional text readability formulas have been criticized by discourse analysts as being weak indicators of comprehensibility and as not supporting cognitive processes involved in text comprehension (McNamara \& Magliano 2009). Additionally, they do not account for the characteristics of readers or text-based factors like syntactic complexity, rhetorical organization, and propositional density (Carrell 1987). From the L2 perspective, Brown (1998) has identified that traditional readability formulas are not highly predictive of L2 reading difficulty. Based on psycholinguistic and cognitive models of reading, traditional readability does not take into account comprehension factors such as coherence (Gernsbacher 1997), and meaning construction and cognitive processes such as decoding and syntactic parsing (Perfetti, Landi \& Oakhill 2005). In a nutshell, readability tests are criticized as being too simplistic and fail to consider any of the many other variables which may influence reading or the comprehension of a text (Bitgood 1996; Harrison \& Bakker 1998).

Though traditional readability formulas are found to have had some limitations, they are also predictive of reading difficulty and can discriminate reading difficulty reasonably well for L2 students (Greenfield 1999). In addition, traditional readability formulas obliquely account for cognitive processes such as word length and sentence length (Crossley, Allen \& McNamara 2011). One crucial benefit of traditional readability formulas is that they can serve as an early warning signs to alert writers that the text being written might be too dense. Besides, studies have shown that there is positive correlation between readability scores and other measures of reading ease 
and/or comprehension (Woods, Moscardo \& Greenwood 1998). For example, Klare (1984 cited in Woods, Moscardo \& Greenwood 1998) in a review of studies on readability formulas identified that readability test scores were related to:

a. the probability of readers actually reading a piece of text completely;

b. the amount of information remembered by readers;

c. the length of time taken to read a passage;

d. the readers' ratings of difficulty levels.

This implies that readability scores are related to some aspects of text difficulty that are recognized by, and relevant to readers. At this point, it is crucial to expatiate on the readability formulas that were used in this study for readers to understand the analysis of the data collected.

\section{The Gunning FOG Readability test:}

The Gunning FOG Readability test/index is simply referred to as FOG Index. It was developed by an American textbook publisher named Robert Gunning in 1952. He published this readability test in reaction to his observations that high school graduates were unable to read. According to him, most of this reading problem was a writing problem. He was of the opinion that published materials like newspapers were full of "fog" and unnecessary complexities. The fog index is used commonly to confirm that a text can be read easily by the intended audience. The Gunning Fog Index has a manual version but in this study the electronic version was used. The underlying principle of the Gunning Fog Index formula is that short sentences in plain English achieve better scores than long sentences written in complicated language. The ideal score for readability with the fog index is 7 or 8 and anything above 12 is too hard for most people to read. Though the fog index gives a sign of hard to read text, it has some limitations. It must be noted that not all complex words are difficult since some short words can be difficult if they are not used very often. The same can be said about sentences.

\section{The Flesch Reading Ease Formula}

The Flesch Reading Ease Readability Formula is one of the oldest and most accurate. It was developed in 1948 by Rudolph Flesch who is an author and a reading consultant. It is a simple approach to assessing the grade-level of readers. This formula is best suited for school text. It is primarily used to assess the difficulty of a reading passage written in English. Rather than using grade levels, this formula uses a scale from 0 to 100 , with 0 being equivalent to the $12^{\text {th }}$ grade (Senior High School 3) 
and 100 also equivalent to 4th grade (Primary 4). This implies that the higher the score the easier the passage to be read and the lower the score the more difficult the passage.

\section{Flesch-Kincaid Grade Level Test}

A related test which translates the Flesch Reading Ease Test scores to grade level is the Flesch-Kincaid formula. The formula was developed by Peter J. Kincaid and his team in 1975. It is extensively used in education. This formula is used to determine the readability level of various books. This implies that the formula can be used to determine the number of years of formal education generally required to understand a reading text. For example, a readability score of 9.3 means that all things being equal, a ninth grader with English as the native language would be able to read the text. The formula makes it easier for teachers, parents and librarians to select appropriate reading texts for their children/learners.

\section{SMOG Readability Formula}

SMOG (Simple Measure of Gobbledygook) is a reading readability formula which estimate the years of formal education needed to understand a piece of writing. This readability formula was propounded by G. Harry McLaughlin in 1969. The SMOG readability formula was created to address the lapses in other formulas like the FOG. This formula was developed particularly for checking health messages (Hedman, 2008) but has been applied to language learning texts. Though the SMOG formula is seen as being too simplistic, it is preferred in evaluating the difficulty of the language of consumer health related materials (Fitzsimmons, Micheal, Hulley, \& Scott 2010).

\section{The Coleman-Liau Readability Index}

The Coleman-Liau index is a readability test which was designed by Meri Coleman and T. L. Liau to measure the understandability of a text. The output of this test approximates the U.S. grade level thought necessary to comprehend the text. It relies on characters instead of syllables per word. Although opinion varies on its accuracy as compared to the syllable/word and complex word indices, characters are more readily and accurately counted by computer programs than are syllables. The Coleman-Liau has a manual version but the online version was preferred in this study.

\section{Automated Readability Index (ARI)}

Automated Readability Index outputs a number which approximates the grade level needed to comprehend a given reading text. It is a test designed to assess the understandability of a text. For instance, an ARI output of 3 means students in the $3^{\text {rd }}$ 
grade (ages 8-9 years old) should be able to comprehend the test. ARI is derived from ratios representing word difficulty (number of letters per word) and sentence difficulty (number of words per sentence). Out of the six readability tests used in this study, four of them (Flesch-Kincaid, Coleman-Liau Index, SMOG Index and Automated Readability Index) predict the grade level of the reading text, while the remaining two (Flesch Reading Ease and Gunning Fog) predict the difficulty level of the reading text. For example, the SMOG index will indicate that the level of a reading text is grade six (Primary 6), while the Flesch Reading Ease will describe the same reading text as fairly easy to read. The six readability formulas mentioned were used to ensure credibility of the study.

\section{Purpose of the Study}

The purpose of the study was to identify the readability and age levels of comprehension passages from Junior High School English textbooks using readability measuring formulae like the Gunning FOG Readability Test (FOG), the Flesch Reading Ease Formula (FREF), the Flesch-Kincaid Grade Level (F-KGL), the SMOG Index readability tests (SMOG), the Coleman-Liau (C-Liau) and Automated Readability Index (ARI). The study also sought to examine how the writing of English textbooks meant for second language learners as in the case of Ghanaian Junior High Schools can be improved to facilitate reading with understanding based on the available literature.

\section{Research Questions}

The main research questions addressed in this study were as follows:

1. What are the reading difficulty and age levels of comprehension passages in Ghanaian Junior High School English textbooks?

2. What are the implications for improving the writing of Junior High School English textbooks to make them readable and age appropriate?

\section{Methodology}

This study used a mixed methodology; both quantitative and qualitative design approaches. The quantitative data were collected using readability formulas to test the readability of passages in JHS textbooks, while the qualitative data were collected through the use of interviews to examine how such textbooks could be written to make them readable. The purpose of the study was to investigate the readability and age levels of comprehension passages in Junior High School (hereafter JHS) English textbooks in Ghana and how they can be improved to enhance students' reading and 
understanding. English books were selected because English is the language of instruction at the JHS level and all textbooks at this level are written in English with the exception of the Ghanaian languages. Besides, the final examinations of students at this level are written in English. It is also established that there is positive correlation between language performance and performance in other academic disciplines (Owu-Ewie 2012). The JHS level was selected because it is a terminal point for majority of Ghanaian students. In addition, it is assumed that this level of education should inculcate in learners their ability to read and make meaningful judgment from the texts they read. The textbooks used for the study were purposefully selected because they were produced by major publishing houses in Ghana. These major publishing houses were contracted by the Ministry of Education, Ghana to produce the books for the Junior High School. This implies that the publishing houses have the expertise or the resources to contract experts to produce quality books. The books selected are for JHS One, Two and Three. The following textbooks were selected:

Table 1: JHS textbooks used in the study

\begin{tabular}{|l|l|l|l|}
\hline TITLE OF BOOK & PUBLISHERS & YEAR & LEVEL \\
\hline $\begin{array}{l}\text { Junior Secondary School } \\
\text { English }\end{array}$ & $\begin{array}{l}\text { Unimax Macmillan Ltd, Accra, } \\
\text { Ghana }\end{array}$ & 2003 & JHS 1, 2, 3 \\
\hline $\begin{array}{l}\text { New Gateway to English } \\
\text { for Junior High Schools }\end{array}$ & $\begin{array}{l}\text { Sedco } \\
\text { Publishers Limited, Accra, } \\
\text { Ghana }\end{array}$ & 2008 & JHS 1, 2, 3 \\
\hline $\begin{array}{l}\text { Easy Learning English } \\
\text { Language }\end{array}$ & $\begin{array}{l}\text { Excellent Publishing and } \\
\text { Printing, Accra, Ghana. }\end{array}$ & 2009 & JHS 1, 2, 3 \\
\hline $\begin{array}{l}\text { Complete English } \\
\text { Course for Junior } \\
\text { Secondary Schools }\end{array}$ & Step Publishers & 2005 & JHS 1, 2, 3 \\
\hline
\end{tabular}

A book was selected because it has comprehension (reading) passages. Additionally, passages were selected because they had between 150 to 600 hundred words which is the recommended length of a text for the computerized version of the various readability tests used in this study. In all, 12 English textbooks were used; three books representing JHS1, 2, and 3 were selected from each publisher. The study used 48 passages from these textbooks. Four passages were purposefully selected from each textbook (12 passages for each year level and for each publisher) chronologically. That is passage one appears in the book before passage two. The formulas used to 
determine the readability of the passages (texts) were the Gunning FOG Readability test, Flesch Reading Ease Formula, Flesch-Kincaid Grade Level, SMOG Index, Coleman-Liau and Automated Readability Index. These readability tests were used because they are the most commonly used formulas in determining the readability of reading texts. It is also because the researcher had access to the online versions of these readability test formulas. According to Johnson (2000), when comparing the readability of textbooks materials, it is important to use the average of more than one readability index formula. The triangulation of these six readability formulas in this study therefore enhanced credibility.

In addition, the researcher used semi-structured interviews to collect qualitative data from JHS students, JHS teachers and English language lecturers from The Department of English Language Education of the University of Education, Winneba (UEW) to ascertain how JHS English language text can be written to suit the intended readers. In all, 20 participants (10 JHS students, 7 JHS teachers and 3 lecturers) were purposively selected. The JHS teachers were selected because they have used the textbooks used in the study, while the lecturers were selected because they have taught textbook production and evaluation as a course in the university. Oral consents were sought from the teachers before the interviews were conducted and recorded.

The authors of the books were not involved in the study because the Ministry of Education, Ghana had concerted that the books are appropriate for the students. What must be noted finally is that the researcher looked at the books as documents being used in our schools and not the processes involved in the production of these books. Other researchers can investigate the processes involved in the production of these textbooks.

\section{Data Analysis and Discussion of Findings}

This section of the study deals with answering the two main research questions posed in the study. As a recap, the following are the research questions:

1. What are the reading difficulty and age levels of comprehension passages in Ghanaian Junior High School English textbooks?

2. What are the implications for improving Junior High School English textbooks writing to make them readable and appropriate to the grade level?

The analysis in this study is done based on the assumption that the Ghanaian child commences his/her formal basic education at age six. All things being equal, the Ghanaian child will be 12 years, 13 years and 14 years in Junior High School one, two and three respectively. What must also be noted in the analysis for easy 
understanding is that 3 years will be added to any reading age or grade level in the assessment. The rationale for this assumption is that the readability formulas used in this study were meant for assessing the readability of text materials meant for native speakers of English and since Ghanaians start using English (second language) as a medium of instruction from Primary 4 (10 years old) as enshrined in the language policy of education in Ghana (see Owu-Ewie, 2013), it is crucial to do the plus 3. For example, a C-Liau index measure of a material meant for $8^{\text {th }}$ Grade will be $11^{\text {th }}$ Grade, a SMOG grade level of 6 will be 9 and ARI measure of a reading text for11-13 year olds will be 14-17 year olds. The plus 3 calculations will be put in parenthesis against the original measure in the analysis (see Appendix A). However, there will be a subtraction of 3 from the figures of the Flesch Reading Ease Formula (FREF) since the higher the FREF figure the easier the text.

Research Question 1: What are the ages and reading difficulty levels of comprehension passages in Ghanaian Junior High School English textbooks?

In response to this two-tier question, the following analyses were made (see appendix A for sample detailed analysis):

The Gunning Fox text scale and the Flesch Reading Ease Score indicate whether a reading text is difficult to read, hard to read, standard/average, or easy to read, while the Automated Readability Index gives the reading age of the learners the materials are intended for. The Text Readability Consensus column strikes an average of all the readability formulas used and it provides information on reading level and the reader's age which the researcher used to corroborate information in Gunning Fox text scale/the Flesch Reading and the Automated Readability Index. For detailed analysis see sample in appendix A.

\section{a. Age and difficulty level of passages from individual JHS English textbooks}

The data analysis in this section about the individual textbooks showed that most of the passages (texts) were above the age level of readers and were therefore difficult to read. Age appropriate reading materials have been identified as a crucial factor essential to enhancing reading. It is believed that when we select a material which is above the age of the learner, it obstructs reading and the development of good reading skills. The following are the analysis of the passages selected from the various textbooks in relation to age and readability difficulty. 
Table 2: The age and readability difficulty levels of passages in Junior Secondary School English Textbook

\begin{tabular}{|c|c|c|c|c|c|c|}
\hline \multirow{2}{*}{$\begin{array}{l}\text { Junior Secondary } \\
\text { School English }\end{array}$} & \multicolumn{3}{|c|}{ AGE LEVEL } & \multicolumn{3}{|c|}{$\begin{array}{c}\text { READING DIFFICULTY } \\
\text { LEVEL }\end{array}$} \\
\hline & Above Age & $\begin{array}{l}\text { Equal to } \\
\text { age }\end{array}$ & $\begin{array}{l}\text { Below } \\
\text { age }\end{array}$ & Difficult & Standard & $\begin{array}{l}\text { Below } \\
\text { reading } \\
\text { level }\end{array}$ \\
\hline Book 1 & $2(16.7 \%)$ & $2(16.7 \%)$ & 0 & $\begin{array}{c}2 \\
(16.7 \%)\end{array}$ & $2(16.7 \%)$ & 0 \\
\hline Book 2 & $3(25 \%)$ & 0 & $\begin{array}{c}1 \\
(8.3 \%)\end{array}$ & $3(25)$ & $1(8.3 \%)$ & 0 \\
\hline Book 3 & $3(25 \%)$ & $1(8.3 \%)$ & 0 & $4(33.3)$ & 0 & 0 \\
\hline TOTAL & $8(66.7)$ & $3(25 \%)$ & $\begin{array}{c}1 \\
(8.3 \%)\end{array}$ & $9(75 \%)$ & $3(25 \%)$ & 0 \\
\hline
\end{tabular}


Fig. 1: Bar chart of age and readability difficulty levels of passages in Junior Secondary School English Textbook
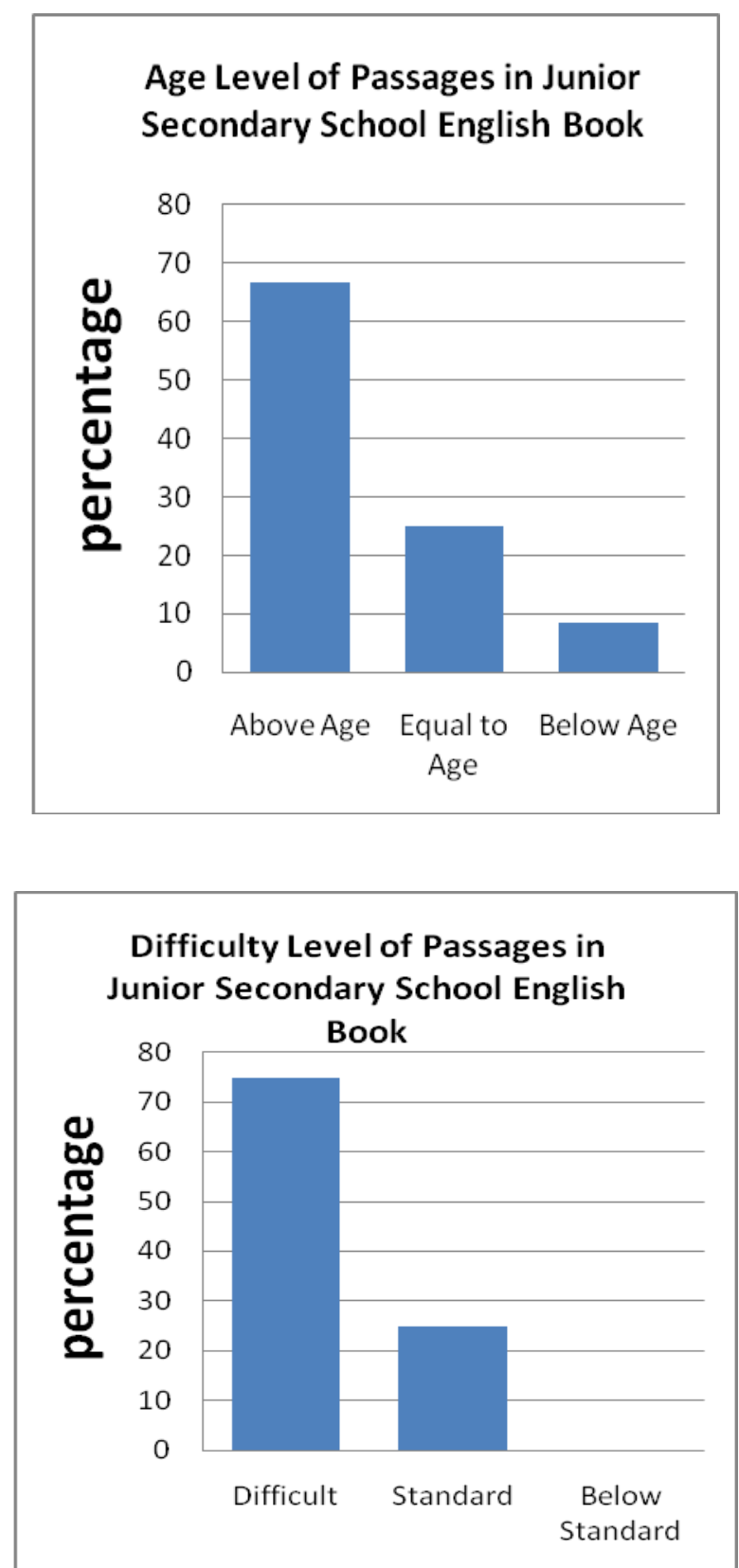

47 
Table 3: The age and readability difficulty levels of passages in Easy Learning English Language Textbook

\begin{tabular}{|c|c|c|c|c|c|c|}
\hline \multirow{2}{*}{$\begin{array}{c}\text { Easy Learning } \\
\text { English Language }\end{array}$} & $\begin{array}{l}\text { Above } \\
\text { Age }\end{array}$ & $\begin{array}{l}\text { Equal to } \\
\text { age }\end{array}$ & $\begin{array}{l}\text { Below } \\
\text { age }\end{array}$ & Difficult & Standard & $\begin{array}{l}\text { Below } \\
\text { reading } \\
\text { level }\end{array}$ \\
\cline { 2 - 7 } & $3(25 \%)$ & $1(8.3 \%)$ & 0 & $3(25 \%)$ & $1(8.3 \%)$ & 0 \\
\hline Book 1 & $4(33.3 \%)$ & 0 & 0 & $\begin{array}{c}4 \\
(33.3 \%)\end{array}$ & 0 & 0 \\
\hline Book 2 & $4(33.3 \%)$ & 0 & 0 & $\begin{array}{c}4 \\
(33.3 \%)\end{array}$ & 0 & 0 \\
\hline TOTAL & $11(91.7 \%)$ & $1(8.3 \%)$ & 0 & $\begin{array}{l}11 \\
(91.7 \%)\end{array}$ & $1(8.3 \%)$ & \\
\hline
\end{tabular}

Fig 2: Bar chart of age and readability difficulty levels of passages in Easy Learning English Language Textbook

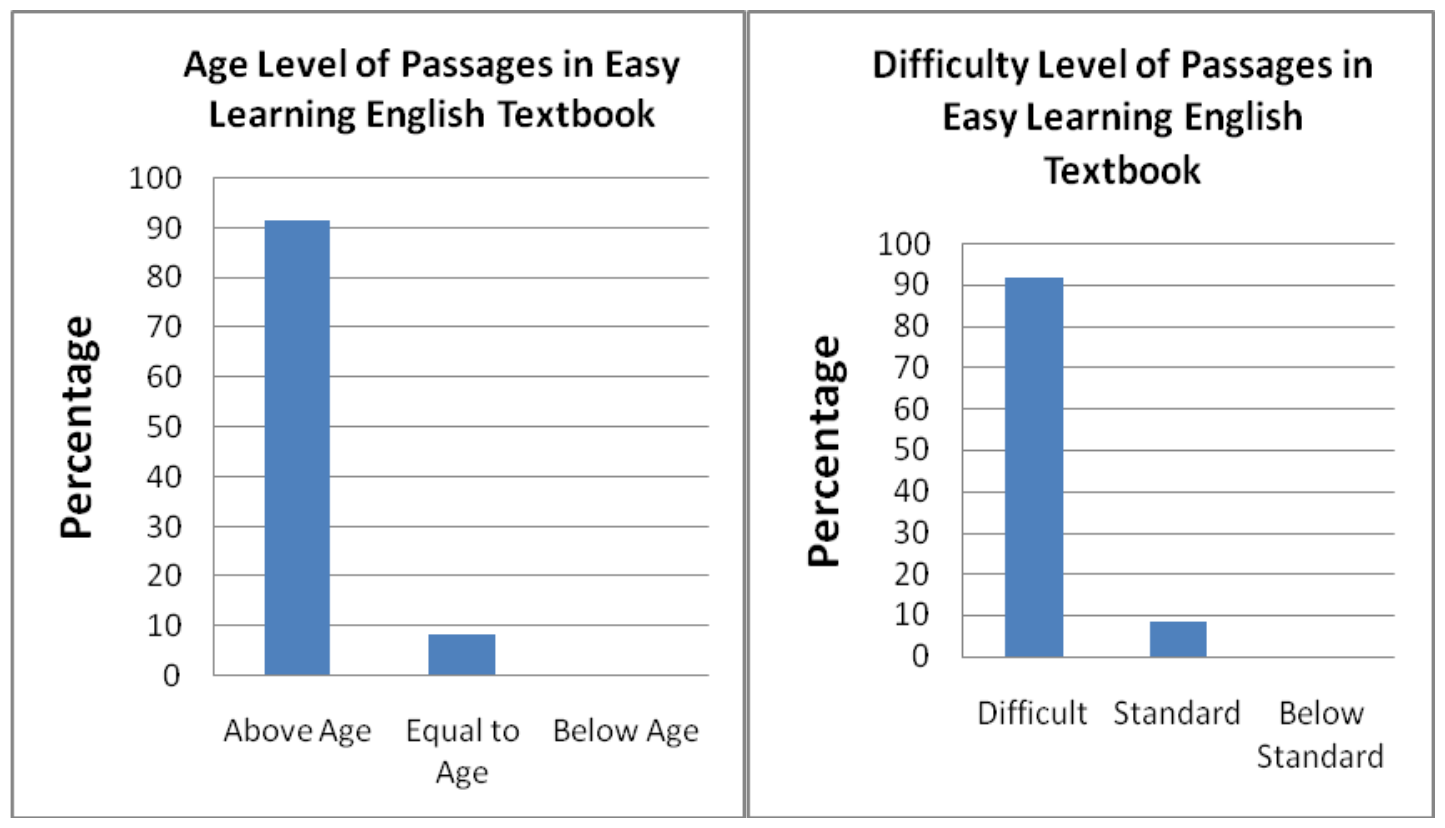


Table 4: The age and readability difficulty levels of passages in Complete English Course for Junior Secondary Schools Textbook

\begin{tabular}{|l|c|c|c|c|c|c|}
\hline & \multicolumn{3}{|c|}{ AGE LEVEL } & \multicolumn{2}{c|}{ READING DIFFICULTY LEVEL } \\
\cline { 2 - 7 } $\begin{array}{l}\text { Complete English } \\
\text { Course for Junior } \\
\text { Secondary Schools }\end{array}$ & Above Age & $\begin{array}{l}\text { Equal to } \\
\text { age }\end{array}$ & $\begin{array}{l}\text { Below } \\
\text { age }\end{array}$ & Difficult & Standard & $\begin{array}{l}\text { Below } \\
\text { reading } \\
\text { level }\end{array}$ \\
\hline Book 1 & $4(33.3 \%)$ & 0 & 0 & $\begin{array}{c}4 \\
(33.3 \%)\end{array}$ & 0 & 0 \\
\hline Book 2 & $1(8.3 \%)$ & $1(8.3 \%)$ & 2 & $1(8.3 \%)$ & $3(25 \%)$ & 0 \\
\hline Book 3 & $3(25 \%)$ & $1(8.3 \%)$ & 0 & $3(25 \%)$ & $1(8.3 \%)$ & 0 \\
\hline TOTAL & $8(66.6 \%)$ & $2(16.7 \%)$ & $\begin{array}{c}2 \\
(16.7 \%)\end{array}$ & $\begin{array}{c}8 \\
(66.7 \%)\end{array}$ & $4(33.3 \%)$ & 0 \\
\hline
\end{tabular}


Fig 3: Bar chart age and readability difficulty levels of passages in Complete English Course for Junior Secondary Schools Textbook
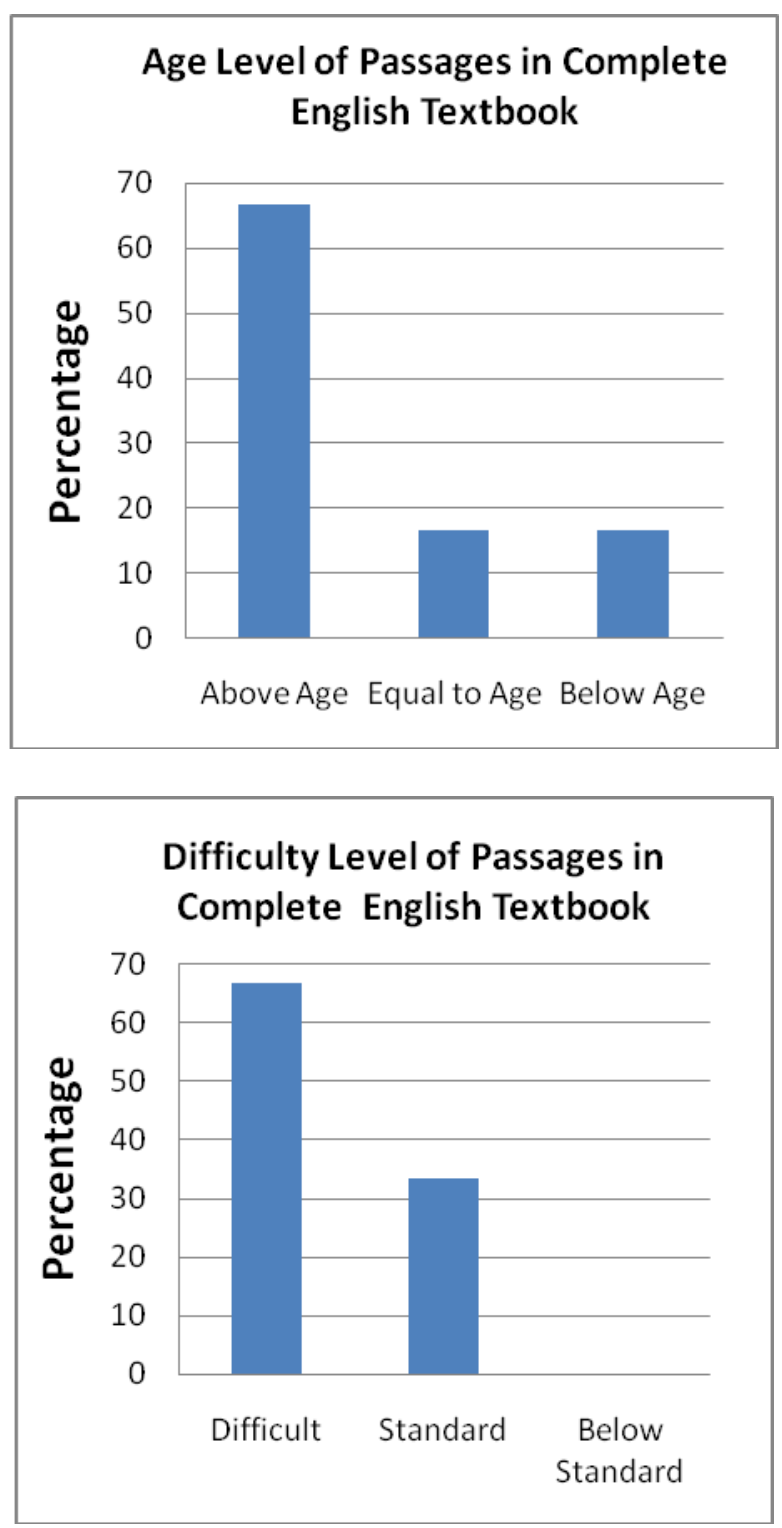
Table 5: The age and readability difficulty levels of passages in New Gateway to English for Junior High Schools Textbook

\begin{tabular}{|c|c|c|c|c|c|c|}
\hline \multirow{2}{*}{$\begin{array}{c}\text { New Gateway to } \\
\text { English for Junior High } \\
\text { Schools }\end{array}$} & $\begin{array}{l}\text { Above } \\
\text { Age }\end{array}$ & $\begin{array}{l}\text { Equal to } \\
\text { age }\end{array}$ & $\begin{array}{l}\text { Belo } \\
\text { w age }\end{array}$ & Difficult & Standard & $\begin{array}{l}\text { Below } \\
\text { reading } \\
\text { level }\end{array}$ \\
\hline Book 1 & $3(25 \%)$ & $1(8.3 \%)$ & 0 & $3(25 \%)$ & $1(8.3 \%)$ & 0 \\
\hline Book 2 & $3(25 \%)$ & $1(8.3 \%)$ & 0 & $3(25 \%)$ & $1(8.3 \%)$ & 0 \\
\hline Book 3 & 4 & 0 & 0 & 4 & 0 & 0 \\
& $(33.3 \%)$ & & & $(33.3 \%)$ & & 0 \\
\hline TOTAL & $\begin{array}{c}10 \\
(83.3 \%)\end{array}$ & $\begin{array}{c}1 \\
(16.7 \%)\end{array}$ & 0 & 10 & $2(16.7 \%)$ & \\
\hline
\end{tabular}

Fig 4: Bar chart of age and readability difficulty levels of passages in New Gateway to English for Junior High Schools Textbook
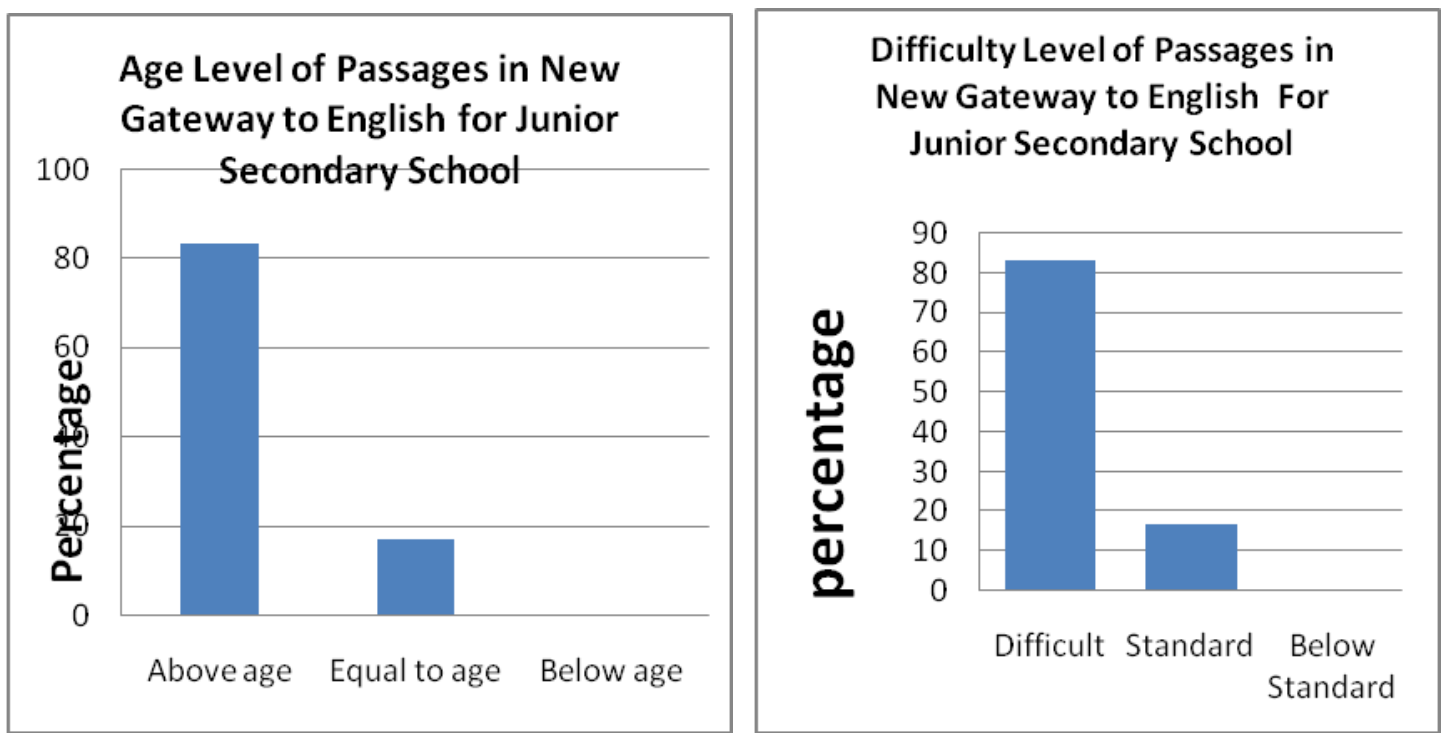


\section{b. Age and difficulty level of passages from JHS English textbooks combined}

The combined data analysis of the selected passages from the textbooks indicated that most of the passages were above the age of the learners (Junior High School students). On individual school basis, the Junior Secondary School textbook has 8 $(66.7 \%)$ of the passages above the age of the learners, $3(25.0 \%)$ is equal to the age of the learners and 1 representing $8.3 \%$ below the age of the learners. The Complete English Course for Junior Secondary Schools has $8(66.6 \%)$ passages above the age of the learners, $2(16.7 \%)$ equal the age of the learners and $2(16.7 \%)$ below the age level of the learners while the Easy Learning textbook had 10 of the passage representing $88.3 \%$ above the age level of the learners, $2(16.7 \%)$ equal to the age of the learners and 0 below the age of the learners. Lastly, the New Gateway to English for Junior High Schools has 11 passage representing $91.7 \%$ above the age of the learners and 1 passage representing $8.3 \%$ was equal to the age of the learners. There was no passage below the age of the learners. This implies that the Gateway English textbooks have more passages above the age level of learners and difficult to read than the other textbooks. The Junior Secondary School textbook and Complete English Course have 1 and 2 passages respectively below the age of the learners. On the whole, 37 (77.1\%) out of the 48 passages are above the age level of the learners in the Junior High School, 8 passages (16.7\%) are equal to the age of the learners and 3 passages $(6.2 \%)$ below the age of the learners.

To the question whether the passages were difficult, standard/average or below standard, it was found that generally 37 passages $(77.1 \%)$ were difficult or hard to read, and $11(22.9 \%)$ were standard/average. There were no passages below the reading level of the learners. The individual books have the following: the Junior Secondary School English has 9 (75\%) difficult passages and $3(25 \%)$ passage to the standard/average for the learners, the Easy Learning textbook has 10 passage (83.3\%) as being difficult to read and $3(25 \%)$ are standard or average, while the Complete English Course has 7 (58.3\%) passages as difficult to be read by learners and 5 $(41.7 \%)$ as standard/average. Lastly, it was realized that the Gateway English textbooks have $11(83.3 \%)$ passages which are difficult to read and 1 passage representing $16.7 \%$ as standard/average. The table below represents the descriptive analysis made above. 
Table 6: The age and difficulty levels of passages in JHS English Textbooks

\begin{tabular}{|l|c|c|c||c|c|c|}
\hline \multirow{2}{*}{\multicolumn{1}{|c|}{ TEXTBOOK }} & \multicolumn{4}{c||}{ AGE LEVEL } & \multicolumn{3}{c|}{ READING DIFFICULTY } \\
& \multicolumn{1}{|c|}{$\begin{array}{l}\text { LEVEL } \\
\text { Ageve }\end{array}$} & $\begin{array}{l}\text { Equal } \\
\text { to age }\end{array}$ & $\begin{array}{l}\text { Below } \\
\text { age }\end{array}$ & Difficult & Standard & $\begin{array}{l}\text { Below } \\
\text { reading } \\
\text { level }\end{array}$ \\
\cline { 2 - 7 } & & 3 & 1 & 9 & 3 & 0 \\
\hline $\begin{array}{l}\text { Junior Secondary School } \\
\text { English }\end{array}$ & 11 & 1 & 0 & 11 & 1 & 0 \\
\hline $\begin{array}{l}\text { New Gateway to English for } \\
\text { Junior High Schools }\end{array}$ & 10 & 2 & 0 & 10 & 2 & 0 \\
\hline $\begin{array}{l}\text { Easy Learning English } \\
\text { Language }\end{array}$ & 8 & 2 & 2 & 7 & 5 & 0 \\
\hline $\begin{array}{l}\text { Complete English Course for } \\
\text { Junior Secondary Schools }\end{array}$ & 37 & 8 & 3 & 37 & 11 & 0 \\
\hline \begin{tabular}{l} 
TOTAL \\
\hline
\end{tabular} & & & &
\end{tabular}

The table above can be represented diagrammatically as in Figure 5. 
Fig.5: Bar graph of the age and difficulty levels of passages in JHS English Textbooks
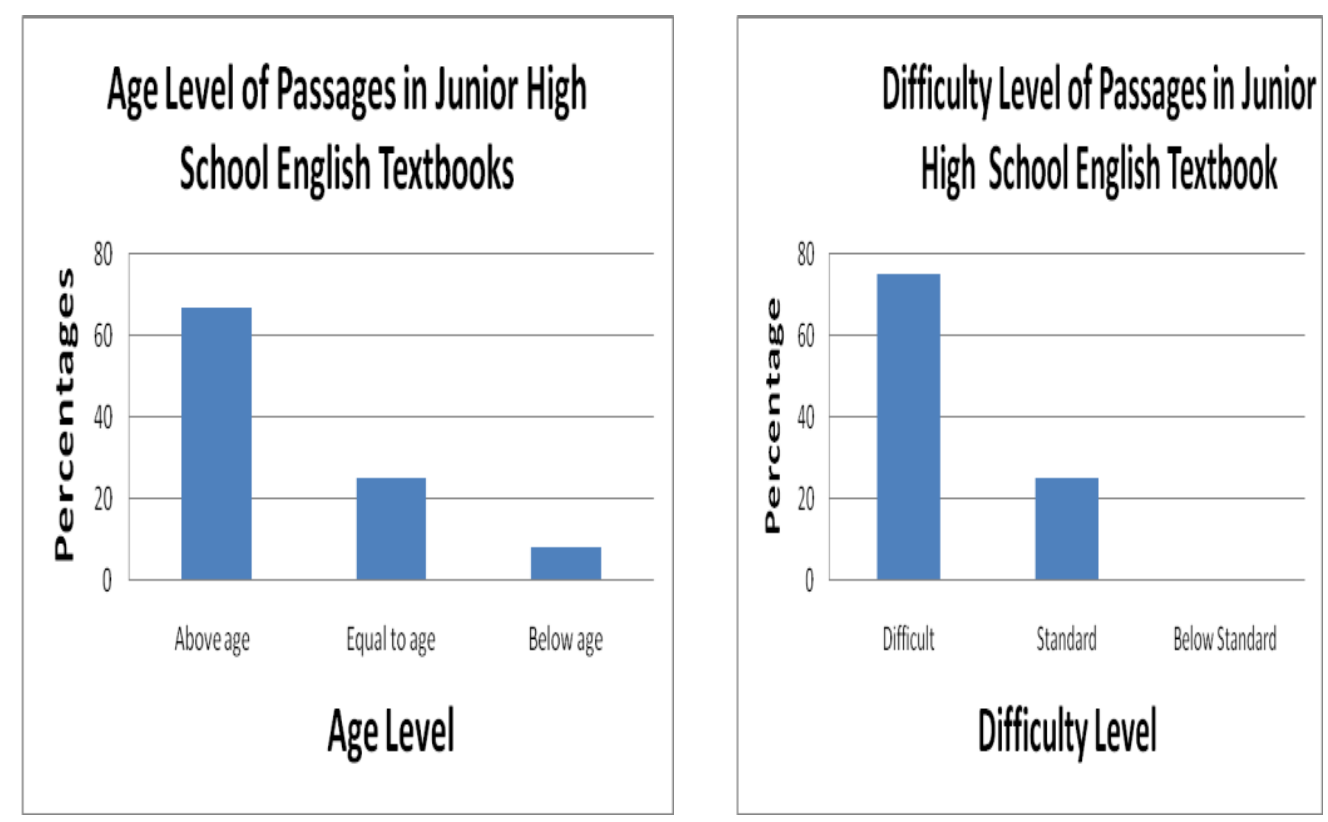

One other interesting finding from the study was that the passages were not in a graded form. One would have expected that the passages will be increasing in terms of difficulty as one reads from unit one through to the last unit but this was not the case in the books used. It was found that some passages in the earlier units were more difficult than those late in the book. It was also realized that some passages in book one were found to be more difficult than those in books two and three. All the selected books were developed devoid of Krashen's (1983) Input Hypothesis in Second Language Acquisition. According to this hypothesis, learners improve and progress along the natural order when the input given is one step beyond the current level of linguistic competence. This implies that passages in each textbook should be in graded form; a current passage should be a step higher than the previous one.

\section{Causes of reading difficulty of passages}

The following were found to be some of the causes why the passages were difficult for students to read: 


\section{a. $\quad$ Nature of sentences}

Research on readability indicates that short sentences in plain English achieve better reading scores than long sentences written in complicated language (Stephens 2000). The analysis showed that some of the sentences used in the Junior High School reading passages were found to be complex, lengthy and convoluted, while others were found to be choppy and unnatural. The nature of these sentences contributed to the difficult nature of most of the passages. Besides the length, the phrases in the sentences are stringed together in such a way that they obscure meaning; they cause processing difficulty. Items which are likely to cause sentence processing difficulty are referred to as "heaviness" (Berman 1984). As Chomsky (1969: 6, as quoted in Essem Educational Limited 2007) puts it, "if two grammatical relations which hold among the words in a sentence are not expressed directly in its surface structure" they pose difficulty of interpretation. Some of the sentences were found to be ambiguous and prone to multiple interpretations. According to Berman (1984), sentence length correlates with difficulty because longer sentences are likely to contain more complex structures such as coordination and subordination. The following are examples extracted from the selected passages:

1. Even though Ghana has adopted many strategies to eliminate poverty and to bring itself to middle-income status by the year 2020, a lot still needs to be done, especially among the rural and urban poor.

2. Access to education is limited and all the things necessary for people to live a happy and comfortable life are lacking: good hospitals, health care centers, good housing, and so on.

3. There was a wooden bench along each side of them, and a space in the middle of the floor, where travellers who had folding stools could sit on them, but although the Fourth Class was not comfortable, it was cheaper than the other three classes, so Marie was going to travel Third Class in Poland and France and Fourth Class across Germany.

4. The healthier alternatives is either to drink a lot of water (five pure water sachets a day) that flushes out the body as chemical toxins and rejuvenates the body cell, or lots of the natural fresh fruits juice such as pineapples, orange, or even coconut juice which are very nutritious and contain all the essential vitamins, minerals and nutrients that these soft drinks lack. 
5. White bread is actually refined, bleached white flour that has been stripped of all its nutritional values and vitamins and to it has been added white sugar and white salt (both deadly) to produce the tea bread, sugar butter bread, etc.

6. The healthier alternatives is either to drink a lot of water (five pure water sachets a day) that flushes out the body's chemical toxins and rejuvenates the body cell, or lots of the natural fresh fruits juice such as pineapple, orange, or even coconut juice which are very nutritious and contain all the essential vitamins, minerals and nutrients that these soft drinks lack.

7. Secondly, the forest, which serves as habitat for animals and birds, will disappear if man does not check the rate at which trees are cut down.

8. After that, people in England had to wait for newspapers to be printed, and probably the majority of the people heard the news by word of mouth.

A critical look at the various sentences identified in the selected passages from the various books indicated that on the average the shortest sentence had nine (9) words, while the longest had sixty-five (65) words as in sentence (4) above. On the average, the Junior Secondary School textbook and Easy Learning have 18 and 17 words per sentence respectively, while Gateway to English for Junior High School and Complete English textbooks have 17 and 16 words per sentence respectively. The lengthy nature of the sentences makes it difficult for learners to read and understand what they read.

\section{b. Age appropriateness}

Age appropriateness is crucial in determining the selection of many variables in learning. The age of a learner determines the method, technique and the level of language used in the classroom. Age also determines the length of a passage and structure of sentences used in the passage. It also helps to specify the font size to use for the text. From the earlier analysis, most of the passages were above the age of the learners.

\section{c.Unfamiliar background}

Background knowledge plays a significant role in reading and understanding of a given text/passage (Pulido 2007; Brantmeier 2005). For example, lack of cultural familiarity in L2 students' reading text has greater impact on reading comprehension (Johnson 1982). Lee (1986) in a study on the role of background knowledge and reading comprehension found that students' ability to understanding and recall are 
enhanced when they are presented with background knowledge and are familiar with a text. This important assumption was deemphasized in the Junior High School English textbooks used in the study. Some passages used in the books were found to have contents which were unfamiliar to the Ghanaian JHS student. This obstructs reading and comprehension of the texts which are already beyond the reading age of learners. Some passages selected for the study did not reflect the cultural background of students. Examples of the passages include Climbing Mount Everest, Scott of the Antarctic, Leaving for a foreign country and Gulliver's Travel. For instance, the text on Leaving for a foreign country, which talks about a Polish girl who was travelling to France to study could have been a Ghanaian girl from the Northern Region of Ghana who travelled to stay with the aunt/elder sister in the Western Region to study in a Senior High School or better still a Ghanaian girl traveling to the United States or Britain to study at Harvard University or Cambridge University respectively.

This phenomenon of unfamiliar background experience affects readability because some teachers find it difficult to understand what they read. The picture/image the texts portray to the teachers and students are unfamiliar Most teachers have not experienced such phenomenon (e.g. snow) before to be able to explain it to their learners. The study noted that some texts were far removed from the culture and background of learners. The implication of this was expressed by some teachers who were interviewed. One respondent indicated, sometimes the passages are not familiar to us. We read but because it is unfamiliar to us we find it difficult to understand and create mental image of what we read. If they are difficult for us to understand, then what will happen to the students? Another teacher indicated, our students find it difficult to understand some of the passages they read because do not relate to the background or culture of the students. A lecturer interviewed stated what obstructs fluent reading and makes understanding of a text difficult is when the text is unfamiliar to learners in terms of vocabulary, sentence structure and a background which does not reflect the culture of the reader.

All students involved in the study indicated that most of the passages in the JHS English textbooks are difficult for them to read. A second year student indicated sometimes I find it difficult to understand what I read because they talk about things I have not seen before and also the words are difficult for me.

\section{Implications for Improving Junior High School English Textbook Writing}

This section of the research answers the second research question, "What are the implications for improving the writing of Junior High School English textbooks to make them readable and age appropriate?" 
The implications of this study for improving the writing/production of English supplementary reading texts in general and Junior High School English textbooks in particular were found to involve lexical, sentence structure and pedagogical issues. The analysis of the data from the interview revealed the following as implications to improving readability of JHS English textbooks in Ghana:

\section{a. Sentence Use}

As indicated earlier in the study, most sentences found in the passages used for the study were very complex and sometimes difficult to read and understand. The sentences were indeed "heavy". A factor which militates against making a reading material unreadable is the complexity of sentences used by the writers in relation to the reading ability of the reader. Materials meant for second language learners become readable and understandable when unnecessary and distracting information are removed. This implies that sentences used in the reading texts of second language learners, especially for beginners should be simple, precise and unambiguous. Schramm (1947) indicates shorter sentences and concrete items help learners to make sense of any written text. In addition, writers should understand possible problems that are associated with sentence structures such as sentence fragment, run-on sentences, loose sentences, choppy sentences, excessive subordination, and use of parallel structures. Most teachers interviewed had these to say in response to how readability of the JHS English textbooks can be improved in terms of their use of sentence structures:

Most of the sentences are lengthy and sometimes difficult to understand so I think the sentences in these books should be simple and straightforward. It is better to write simple sentences which are understood by learners than to write complex and winding sentences which are difficult to read and understand.

In my opinion, some of the vocabulary used in the sentences are [sic] difficult to understand. Most of the time, we need to use the dictionary. I therefore think we need to use vocabulary and sentence structures which are appropriate to the age of the learners because when the words in the text are difficult to understand it makes the students read slowly and this brings about frustration.

The sentences should be simple but a few can also be long with appropriate conjunctions so that we can teach our students how to use conjunctions.

Sometimes, the sentences are so complex that they become difficult to identify the main clause or clauses and the subordinate clauses where we can use to help 
students practice the use of these sentences in their writing so I think writers should use good sentence structures in their writings to enhance meaning. [sic]

From the above responses, one can conclude that teachers prefer the use of meaningful simple sentences which aid readability. They are also of the opinion that in the event where compound or complex sentences are used, they should have their various clauses clearly written so that the various components can be easily identified. Respondents were also of the view that to help learners learn how to construct clear and unambiguous sentences, their textbooks could have both compound and complex sentences but must be clearly marked with conjunctions and modifiers placed at the appropriate places to aid understanding. The use of parenthesis should most of the time be avoided and where possible, they should be written as independent sentences. The "heaviness" of most sentences in Junior High School English textbooks should be made "light". Reading materials meant for struggling readers like most Ghanaian Junior High School students should be simpler in nature to promote functional literacy and establish fundamental reading habits among learners. As noted by Stephens (2000), more readable texts result in greater and more complete learning and also increase the amount read in a given time.

\section{b. $\quad$ Text-structure}

Text structure, text coherence and cohesion, and syntax also have great effects on the readability of a text. If a reading text has poor paragraphing and lacks proper use of cohesive words to ensure cohesion, readability and understanding suffers. The participants interviewed were of the opinion that reading texts should be properly organized. The paragraphs should be well developed and clearly marked out so that students can organize their thoughts as they read. They were also of the opinion that transitional words should be properly used to ensure that there is cohesion in the text which will invariable ensure readability and comprehensibility. Both global and local coherence should be improved in reading materials. This will serve as writing model for Junior High School learners learning English as a second language. Writers should also employ the appropriate elaboration techniques in the developments of their various paragraphs.

\section{c.Use of familiar texts/genres}

The nature of language input affects reading performance. If the language and background of a reading text (genre) is unfamiliar to readers, it can be hypothesized that the task of comprehending the text will be difficult. This is likely to affect readability. Paltridge (1996) and Fountas and Pinell (2001) attest to this that students' 
performance in reading comprehension tests could be sensitive to the different 'genres' and 'text types' used. The interactive model of reading, which is based on the schema theory of learning, holds the view that readers make connections between the new information they read and prior knowledge. This implies that if readers have prior knowledge of or are familiar with the text they are reading, comprehensibility is enhanced likewise readability. Readers need an understanding of the socio-cultural context and the setting of a given text to facilitate comprehension. This means that textbook writers should take the socio-cultural context of the readers into consideration when writing comprehension passages for Junior High School students. With the local learner in mind, the theme portrayed in a passage could be universal but should be tailored relatively to meet the Ghanaian learner.

\section{d. The role of textbook writers/publishers}

Textbook writers have a major role to play in enhancing readability among their readers, especially Junior High School students. In the first place, textbook writers should have training in textbook writing in general and writing for second language learners in particular. Such training should involve how to write age and context appropriate materials. Besides content knowledge in English, textbook writers should be trained in second language learning and acquisition pedagogy, especially in reading and its various components. Such writers should be second language specialists. Thus, people who are well grounded in second language teaching and learning. In addition to the above, textbook writers and publishers should be familiar with the various ways of (both theory and practical) testing the readability of the materials they write and how to enhance the readability of a text, especially those meant for second language learners.

In concluding this section, it will be appropriate to highlight the role of the classroom teacher in making a reading text with low readability more readable and comprehensible to learners. First, teachers must be conversant with the material to be read before using the reading passages. Again, teachers should have enough prereading activities with learners before they begin to read the text. This implies that teachers should do a lot of background research on passages to be read before the actual teaching. They can research on technical and unfamiliar topics used as reading texts to be familiar with the text prior to teaching it. In a nutshell, teachers should be resourceful so that they could be the link between making unreadable material readable. 


\section{Recommendation for further studies}

The study covered assessing the readability and difficulty level of reading passages in Junior High School English textbooks in Ghana. The assessment was done using readability formulas. The limitation of this study is that the readability formulas used in the study did not take into consideration other factors like background and vocabulary knowledge and how they affect readability. Further studies need to be conducted using practical ways of assessing text readability like the Cloze and Assessment Performance Unit (APU) Vocabulary test and with increased number of comprehension passages from the same textbooks. In addition, further investigations can be done to find out whether the authorities who approved these books have the requisite expertise and knowledge to make informed decision about selecting ageappropriate and readable textbooks.

\section{Conclusion}

The study sought to determine the readability of comprehension passages in Junior High School (JHS) English language textbooks in Ghana and examine ways that readability can be improved in relation to writing texts for second language learners. The study used six readability formulas to analyze 48 comprehension passages selected from four English language textbooks. In addition, semi-structured interview was used to collect information for improving readability. The study found that most of the passages used were above the age of readers and were therefore difficult to read. The study also identified that the nature of sentences, unfamiliar background of passages were some contributing factors. According to the study, readability can be improved by the use of simple, precise and unambiguous sentences, well-structured text and use of familiar or cultural-friendly texts/genres. In addition, the study has indicated that people engaged in textbook writing should be provided with adequate training, especially how to write for second language learners. Most importantly, teachers have a major role to play to turn a text with low readability to one which will be easy to read and understand. 


\section{References}

Allen, D., 2009. A study of the role of relative clauses in the simplification of news text for learners of English. Systems 37.4: 585-599.

Berman, R. A., 1984. Syntactic components of the foreign language reading process. In J. C. Alderson and A. H. Urquhart (eds). Reading in a foreign language (pp. 139-156). New York, NY: Longman.

Bitgood, S. C., 1996. Aspects of Literacy. Canberra: Australian Bureau of Statistics.

Brantmeier, C., 2005. Anxiety about L2 reading or L2 reading tasks? A study with advanced learners. The Reading Matrix 5.2: 67-85.

Brown, J. D., 1998. An EFL readability index. JALT Journal 20: 7-36.

Carrell, P. L., 1987. Readability in ESL. Reading in a Foreign Language 4.1: 21-40.

Crossley, S. A., D. Allen and D. S. McNamara, 2011. Text simplification and comprehensible input: A case for an intuitive approach. Reading in a Foreign Language 23.1: 84-101.

Crossley, S. A., P. M. McCarthy and D. S. McNamara, 2006. Discriminating between second language learning text-types. American Association for Artificial Intelligence. Retrieved from www.aaai.org. 13/6/13

DuBay, W. H., 2004. The principles of readability. Retrieved from en.copian.ca/lidrary/research/readab/readab.pdf

Essem Educational Limited, 2007. Readability: How readable are your texts. Retrieved from www.readability.biz/indices.html, on 13/2/13

Fitzsimmons, P., B. Micheal, J. Hulley and G. Scott, 2010. A readability assessment of online Parkinson's disease information. Journal of the Royal College of Physicians of Edinburgh 40.4: 292-296.

Fountas, I. and G. S. Pinell, 2001. Guiding Readers and Writers Grades 3-6: Teaching Comprehension, Genre, and Content Literacy. Portsmouth, NH: Heinemann.

Fry, E., 2006. Readability: Reading Hall of Fame Book. Newark, DE: International Reading Association.

Gernsbacher, M., 1997. Coherence cues mapping during comprehension. In J. Costermans and M. Fayol (eds.), Processing Interclausal Relationships. Studies in the Production and Comprehension of text (pp. 3-22). Mahwah, NJ: Lawrence Erlbaum Associates. 
Grabe, W. and F. L. Stoller, 2002. Teaching and Researching Reading. London: Pearson Education.

Greenfield, G., 1999. Classic readability formulas in an EFL context: Are they valid for Japanese speakers. Unpublished doctoral dissertation in temple university, Philadelphia, PA: USA.

Harrison, S. and P. Bakker, 1998. Two new readability predicators for professional writer: Pilot trials. Journal of Research in Reading 21: 121-138.

Hedman, A. S., 2008. Using the SMOG formula to revise a health related document. American Journal of Health Education 39.1: 61-64.

Johnson, K., 2000. Readability. Retrieved from www.timetabler.com on 12/03/2013.

Kincaid, J. P., R. P. Fishburne, R. L. Rogers and B. S. Chissom, 1975. Derivation of new readability formulas for Navy Enlisted Personnel. Research Branch Report 8-75. Millington, TN: Naval Technical Training: Memphis.

Klare, G. R., 1963. The measurement of readability. Ames, IA: Iowa State University Press.

Krashen, S., 1983. Principles and Practice in Second Language Acquisition. Oxford: Pergamon Press.

Lee, J. F., 1986. Background knowledge and L2 reading. Modern Languages Journal 70: 350-354.

McNamara, D. S. and J. P. Magliano, 2009. Self-explanation and metacognition: The dynamics of reading. In J. D. Dunlosky and A. C. Graesser (eds.), Handbook of Metacognition in Education (pp. 60-81).Mahwah, NJ: Erlbaum.

Ministry of Education, Canada (2003). A guide to effective instruction in reading: Kindergarten to Grade 3. Ontario, Canada: Queen's Printer for Ontario.

Owu-Ewie, C., 2012. Language performance and mathematics/science performance: A correlational case study of JHS students in Sekondi/Takoradi and Shama Districts. The Buckingham Journal of Language and Linguistics 5: 83-99.

Owu-Ewie, C., 2013. The language policy of education in Ghana in perspectives: The past, the present and the future. Language and Linguistics 32: 39-58.

Paltridge, B., 1996. Genre and the Language-learning Classroom. Ann Arbor: University of Michigan Press. 
Perfetti, C. A., N. Landi and J. Oakhill, 2005. The acquisition of reading comprehension skill. In M. J. Snowing and C. Hulme (eds.). The Science of Reading: A Handbook (pp. 227-247). Oxford: Blackwell.

Pulido, D., 2007. The effects of topic familiarity and passage sight vocabulary on L2 lexical inferencing and retention through reading. Applied Linguistics, 28: 66-86.

Schramm, W., 1947. Measuring another dimension of newspaper readership. Journalism Quarterly 24: 293-306.

Stephens, C., 2000. All about Readability.

Retrieved from http://plainlanguage.com/newreadability on12/04/12.

Reece, I. and S. Walker, 1992. A Practical Guide to Teaching, Training and Learning. Great Britain: Business Education Publishers Limited

Woods, B., G. Moscardo and T. Greenwood, 1998. A critical review of readability and comprehensibility tests. The Journal of Tourism Studies 9.2: 49-60. 
Appendix A: (Sample Consensus Readability Test)

Consensus Readability Test for Passages in Complete English

\begin{tabular}{|c|c|c|c|c|c|c|c|c|}
\hline \multicolumn{2}{|c|}{ BOOK } & \multicolumn{7}{|c|}{ READABILITY FORMULAS } \\
\hline \multirow{4}{*}{$\begin{array}{c}\text { BOOK } \\
1\end{array}$} & PASSAGES & FOG & FREF & F-KGL & SMOG & C-Liau & ARI & $\begin{array}{l}\text { READABILITY } \\
\text { CONSENSUS }\end{array}$ \\
\hline & 1 & $\begin{array}{l}\text { Text scale } \\
11.8 \\
\text { Hard to } \\
\text { read }\end{array}$ & $\begin{array}{l}\text { Text } \\
\text { Scale } \\
61.9 \\
\text { Standard/ } \\
\text { average }\end{array}$ & $\begin{array}{l}\text { Grade } \\
\text { Level } 9.4 \\
9^{\text {th }} \text { Grade } \\
\left(12^{\text {th }}\right. \\
\text { Grade })\end{array}$ & $\begin{array}{l}\text { Index } 9.2 \\
\text { Grade } \\
\text { level } 9 \\
\text { (Grade } \\
\text { level 13) }\end{array}$ & $\begin{array}{l}\text { Index } \\
10 \\
10^{\text {th }} \\
\text { Grade } \\
\left(13^{\text {th }}\right. \\
\text { Grade })\end{array}$ & $\begin{array}{l}\text { Index } 10 \\
9^{\text {th }} / 10 \text { th } \\
\text { Graders } \\
\text { for } 14-15 \\
\text { yrs olds } \\
(17-18 \\
\text { yrs old })\end{array}$ & $\begin{array}{l}\text { 9th/10th (12/13) } \\
\text { Graders } \\
\text { Standard/ average } \\
\text { Reading age - } \\
\text { 14-15yrs (17-18 } \\
\text { yrs) }\end{array}$ \\
\hline & 2 & $\begin{array}{l}\text { Text scale } \\
10.1 \\
\text { Hard to } \\
\text { read }\end{array}$ & $\begin{array}{l}\text { Text } \\
\text { Scale } \\
62.8 \\
\text { Standard } \\
\text { / } \\
\text { Average }\end{array}$ & $\begin{array}{l}\text { Grade } \\
\text { Level } 9.3 \\
9^{\text {th }} \text { Grade } \\
\left(12^{\text {th }}\right. \\
\text { Grade })\end{array}$ & $\begin{array}{l}\text { Index } 9 \\
\text { Grade } \\
\text { level } 9 \\
\text { (Grade } \\
\text { level 12) }\end{array}$ & $\begin{array}{l}\text { Index } 9 \\
9^{\text {th }} \\
\text { Grade } \\
\left(12^{\text {th }}\right. \\
\text { grade })\end{array}$ & $\begin{array}{l}\text { Index } 8.6 \\
8^{\text {th }} / 9^{\text {th }} \\
\text { Graders } \\
\text { for } 13-15 \\
\text { yrs olds } \\
((16-18 \\
\text { yrs })\end{array}$ & $\begin{array}{l}9^{\text {th }} \text { Grades } \\
\text { Standard / } \\
\text { average } \\
\text { Reading age - } \\
13-15 \text { yrs (16-18 } \\
\text { yrs) }\end{array}$ \\
\hline & & Text scale & $\begin{array}{l}\text { Text } \\
\text { Scale }\end{array}$ & Grade & Index 7.5 & Index 9 & $\begin{array}{l}\text { Index } 7.6 \\
7^{\text {th }} / 8 \text { th }\end{array}$ & 6th/7th Grades \\
\hline
\end{tabular}




\begin{tabular}{|c|c|c|c|c|c|c|c|c|}
\hline & 3 & $\begin{array}{l}8.8 \\
\text { Fairly easy } \\
\text { to read }\end{array}$ & $\begin{array}{l}75.8 \\
\text { Fairly } \\
\text { easy to } \\
\text { read }\end{array}$ & $\begin{array}{l}\text { Level } 7.6 \\
8^{\text {th }} \text { Grade } \\
\left(11^{\text {th }}\right. \\
\text { Grade })\end{array}$ & $\begin{array}{l}\text { Grade } \\
\text { level } 8 \\
\text { (Grade } \\
\text { level11) }\end{array}$ & $\begin{array}{l}9^{\text {th }} \\
\text { Grade } \\
\left(12^{\text {th }}\right. \\
\text { Grade })\end{array}$ & $\begin{array}{l}\text { Graders } \\
\left(10^{\text {th }} / 11^{\text {th }}\right. \\
\text { Graders }) \\
\text { for } 12-14 \\
\text { yrs. olds } \\
\text { (15-17 } \\
\text { yrs. old })\end{array}$ & $\begin{array}{l}\begin{array}{l}\text { Fairly easy to } \\
\text { read }\end{array} \\
\text { Reading age - 12- } \\
14 \text { yrs. (15-17 yrs } \\
\text { old) }\end{array}$ \\
\hline & 4 & $\begin{array}{l}\text { Text scale } \\
12.9 \\
\text { Hard to } \\
\text { read }\end{array}$ & $\begin{array}{l}\text { Text } \\
\text { Scale } \\
59.1 \\
\text { Fairly } \\
\text { difficult } \\
\text { to read }\end{array}$ & $\begin{array}{l}\text { Grade } \\
\text { Level } 9.8 \\
10^{\text {th }} \text { Grade } \\
\left(13^{\text {th }}\right. \\
\text { Grade })\end{array}$ & $\begin{array}{l}\text { Index } 9.2 \\
\text { Grade } \\
\text { level } 9 \\
(12)\end{array}$ & $\begin{array}{l}\text { Index } 9 \\
9^{\text {th }} \\
\text { Grade } \\
\left(12^{\text {th }}\right. \\
\text { Grade })\end{array}$ & $\begin{array}{l}\text { Index } 9.7 \\
9^{\text {th }} / 10^{\text {th }} \\
\text { Graders } \\
\text { for } 14-15 \\
\text { yrs olds } \\
(17-18 \\
\text { yrs })\end{array}$ & $\begin{array}{l}\text { 9th/10th Grades } \\
\text { Fairly difficult to } \\
\text { read } \\
\text { Reading age - } \\
\text { 14-15 yrs (17-18 } \\
\text { yrs) }\end{array}$ \\
\hline \multirow[t]{2}{*}{$\begin{array}{c}\text { BOOK } \\
2\end{array}$} & 1 & $\begin{array}{l}\text { Text scale } \\
8.6 \\
\text { Fairly easy } \\
\text { to read }\end{array}$ & $\begin{array}{l}\text { Text } \\
\text { Scale } \\
75.1 \\
\\
\text { Fairly } \\
\text { easy to } \\
\text { read }\end{array}$ & $\begin{array}{l}\text { Grade } \\
\text { Level } 6.1 \\
6^{\text {th }} \text { Grade } \\
\left(9^{\text {th }}\right. \\
\text { Grade })\end{array}$ & $\begin{array}{l}\text { Index } 7.0 \\
\text { Grade } \\
\text { level } 7 \\
\text { (Grade } \\
\text { level 10) }\end{array}$ & $\begin{array}{l}\text { Index } 8 \\
8^{\text {th }} \\
\text { Grade } \\
\left(11^{\text {th }}\right. \\
\text { Grade })\end{array}$ & $\begin{array}{l}\text { Index } 5.5 \\
5^{\text {th }} / 6^{\text {th }} \\
\text { Graders } \\
\text { for } 8-9 \\
\text { yrs olds } \\
(11-12 \\
\text { years })\end{array}$ & $\begin{array}{l}6 \text { th } / 7 \text { th Grades } \\
\left(9^{\text {th }} / 10^{\text {th }} \text { Grades }\right) \\
\text { Fairly easy to } \\
\text { read } \\
\text { Reading age - } \\
11-13 \text { yrs (14 -16 } \\
\text { years) }\end{array}$ \\
\hline & 2 & $\begin{array}{l}\text { Text scale } \\
6.3 \\
\text { Fairly easy } \\
\text { to read }\end{array}$ & $\begin{array}{l}\text { Text } \\
\text { Scale } \\
81.5 \\
\text { Easy to } \\
\text { read }\end{array}$ & $\begin{array}{l}\text { Grade } \\
\text { Level } 4.3 \\
4^{\text {th }} \text { Grade } \\
\left(7^{\text {th }}\right. \\
\text { Grade })\end{array}$ & $\begin{array}{l}\text { Index } 7^{\text {th }} \\
\text { Grade } \\
\text { level } \\
\text { (Grade } \\
\text { level 10) }\end{array}$ & $\begin{array}{l}\text { Index } 7 \\
7^{\text {th }} \\
\text { Grade } \\
\left(10^{\text {th }}\right)\end{array}$ & $\begin{array}{l}\text { Index } 3.2 \\
3^{\text {rd }} / 4^{\text {th }} \\
\text { Graders } \\
\text { for 6-7 } \\
\text { yrs olds } \\
(11-12 \mathrm{yr}\end{array}$ & $\begin{array}{l}\text { 4th/5th Grades } \\
\text { Easy to read } \\
\text { Reading age - } 8 \text { - } \\
9 \text { yrs (11-12 } \\
\text { years) }\end{array}$ \\
\hline
\end{tabular}




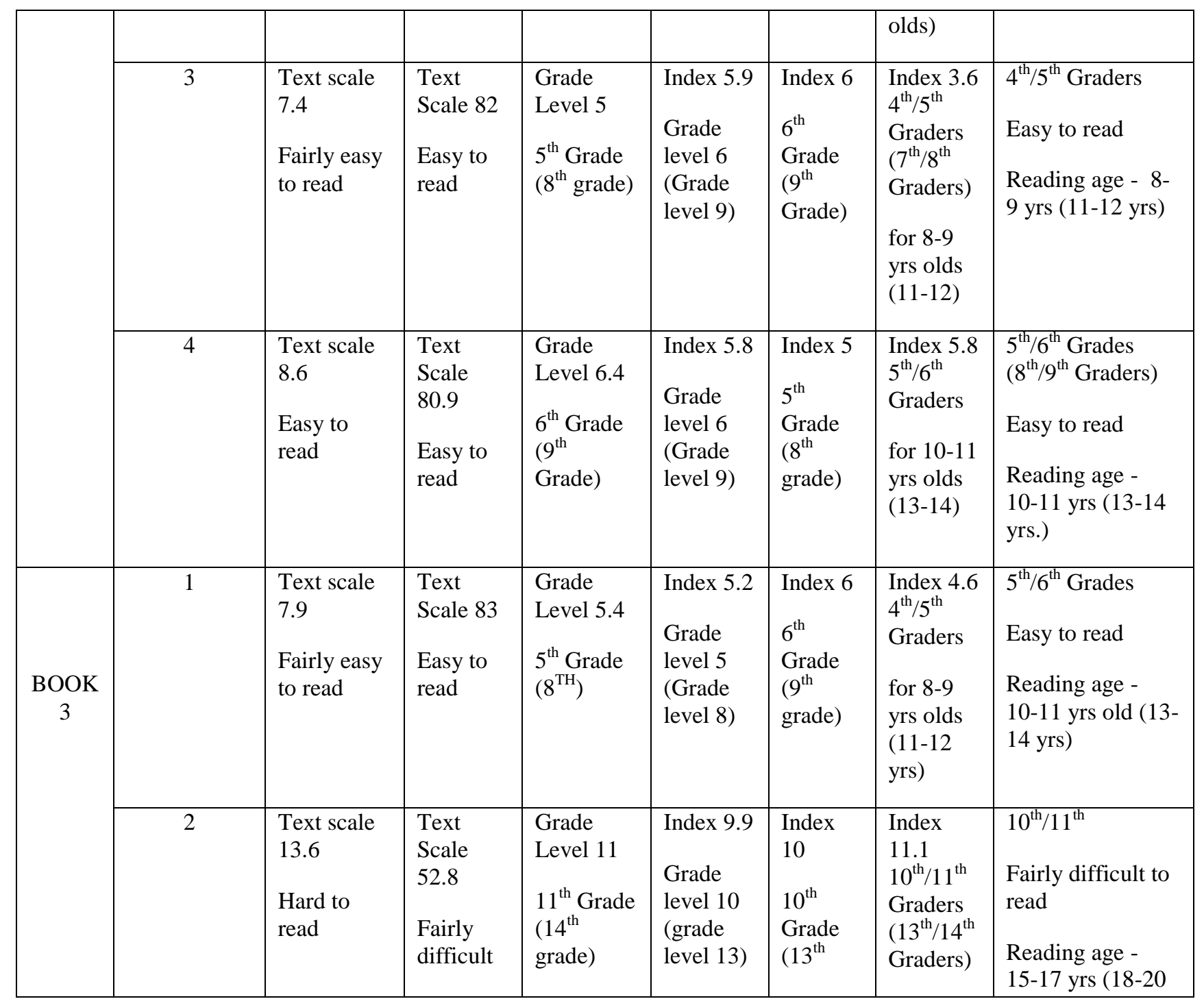




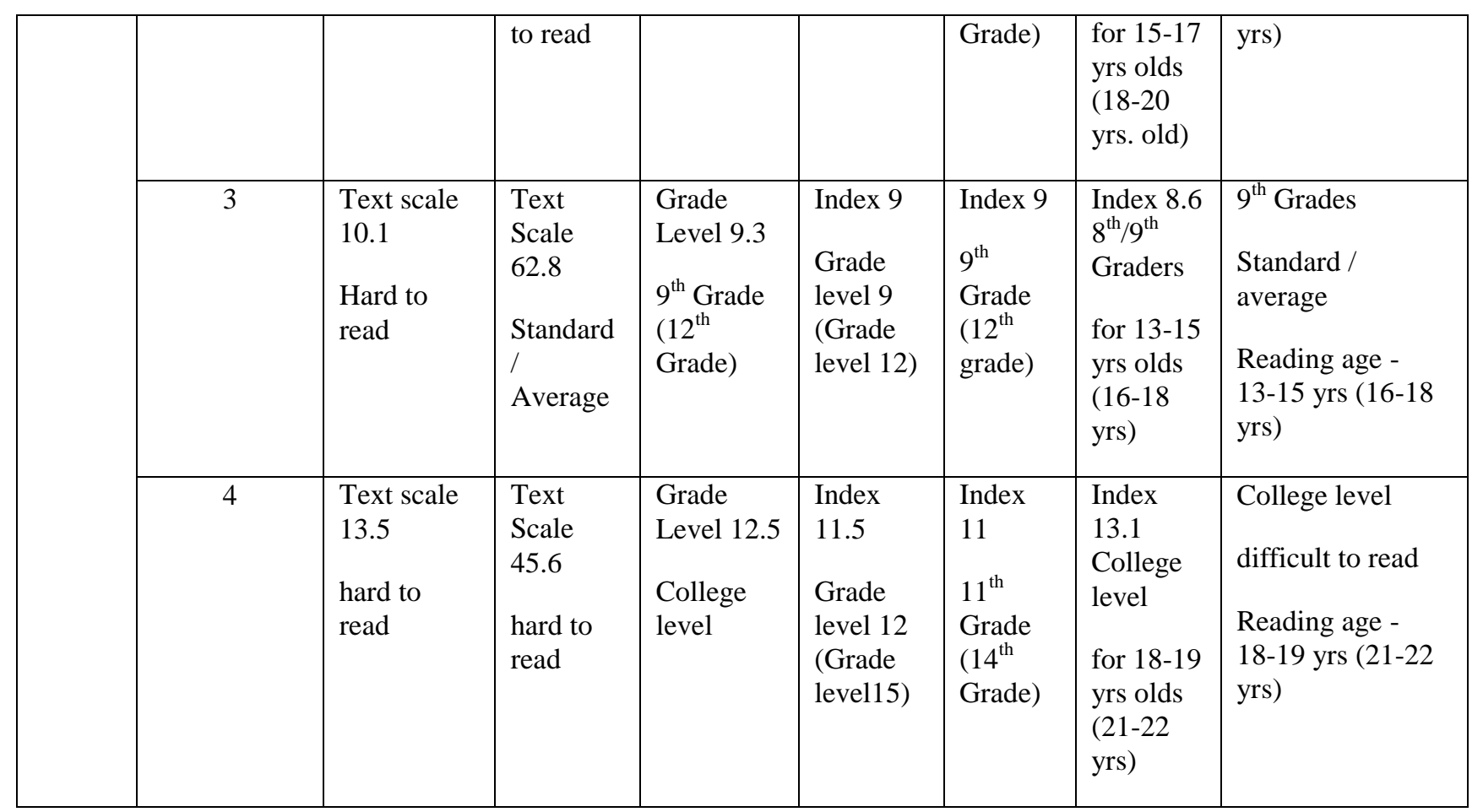

